China Perspectives

$2012 / 3$ | 2012

Locating Civil Society

\title{
Local governments under pressure: The commodification of stability maintenance
}

\section{Jérôme Doyon}

Translator. Elizabet Laederich

\section{OpenEdition \\ Journals}

\section{Electronic version}

URL: http://journals.openedition.org/chinaperspectives/5973

DOI: 10.4000/chinaperspectives.5973

ISSN: 1996-4617

Publisher

Centre d'étude français sur la Chine contemporaine

\section{Printed version}

Date of publication: 1 October 2012

Number of pages: 80-82

ISSN: 2070-3449

\section{Electronic reference}

Jérôme Doyon, «Local governments under pressure: The commodification of stability maintenance », China Perspectives [Online], 2012/3 | 2012, Online since 01 October 2012, connection on 15 September 2020. URL : http://journals.openedition.org/chinaperspectives/5973

(c) All rights reserved 
mittee with members of the legal profession. Participation in the actual reform discussions was limited mainly to national and local experts, however, and the general public was not consulted. As Li Xiangning and Xu Kai wrote in Caijing and Yao Dongxing said in Zhongguo jingji zhoukan, the bulk of the legislative process was focused on power games between different state organs: the Supreme Court, the legislature, the Ministry of Public Security, the public prosecutors, the Ministry of Justice, and other branches of government. The official narrative of reform emphasised public participation, but the real debate took place mostly at the state level. However, the reform committee did at least involve stakeholders in the judicial system in the formulation of reform.

The Ministry of Public Security was quick to get involved in the debate, issuing a series of proposals that were mainly aimed at strengthening the powers of the police. Not all of these proposals were adopted. Li Xiangning and Xu Kai say that no state organ managed to take complete control of the process, and the final version was a compromise between the viewpoints of the legislature (lifa bumen 立法部门), the judiciary, and the police (sifa zhifa bumen 司法执法部门). Their dialogue showed they recognised "the logic of negotiation" (tanpan de luoji 谈判的逻辑). Debate did take place among various public actors, but few of them were outside state organs; experts were really only consulted in an advisory capacity.

The conclusion of the reform process saw the end of the debate. Critical articles were published only while the law was still under discussion. Articles published after the adoption of the law ignored any remaining misgivings, and instead mostly highlighted the advances made in protecting fundamental freedoms.

I Translated by Elizabeth Laederich.

\section{Local governments under pressure: The commodification of stability maintenance}

\section{Analysis by Jérôme Doyon based on:}

- Xu Kai and Li Wei'ao, "The stability maintaining machine," Caijing, 6 June 2011. (1)

- Zhong Weijun, "The 'zero-incident' logic of local governments in maintaining stability: An analytical framework," Zhejiang shehui kexue Zhejiang social sciences, no. 9, September 2011. (2)

- Gao Jun, "The trap of maintaining stability and how to avoid it," Lilun daokan, no. 11, 2011. (3)

- Xia Nan, "The alienation of weiwen," Caijing, 12 October 2011.(4)

- Zhang Qianfan, "The origin and disruption of the system for petitioning the higher authorities," Tansuo yu zhengming - Exploration and free views, 10 May 2012. (5)

n 1994, the Chinese government carried out a tax reform that limited the revenues of local governments and made them dependent for funding on central authorities. Since then, local governments have been caught between the people, who want more social policies that local authorities cannot afford, and the central government, which is focused on maintaining social stability. Xu Kai, Li Wei'ao, and Xi Nan say that social stability has become the main priority of local governments. So, for example, in Yun'an district in the province of Guangdong, out of 6,700 people on the public authorities' payroll, 1,800 have jobs related to maintaining stability. The success of local administrations is evaluated largely on their ability to maintain social stability. In 2009, "The temporary provision on the enforcement of the responsibilities of Party leaders and the State" (guanyu shixing dangzheng lingdao ganbu wenze de zanxing guiding 关于实行党政 领导干部问责的暂行规定) reaffirmed local government's responsibility for incidents that threaten stability, with particular reference to riots and other mass demonstrations. These articles show that this method of evaluation puts pressure on local governments. The central authorities have said that they want to develop the system of "letters and visits" (xinfang 信访), as reaffirmed in 2005's "Regulations on letters and visits" (xinfang tiaoli 信访 条例). This administrative practice, which exists parallel to the judiciary system, allows citizens to appeal local decisions by presenting a petition to central authorities. But evaluating local administrations on the basis of social stability maintenance undermines the system of letters and visits.

In order to appear to be making progress on social stability, local governments have adopted a logic of "zero incidents" (buchushi luoji 不出事逻辑). ${ }^{(6)}$ Whatever the cost, they have to make sure they present an image of stability - even at the risk of not addressing the root causes of various prob-

1. Xu Kai and Li Wei'ao are journalists at Caijing.

2. Zhong Weijun is an associate professor at the School of Political Science and Public Management at the Zheijiang Institute of Technology.

3. Gao Jun is a professor at the School of Humanities and Social Sciences at Jiangsu Teachers University of Technology.

4. Xia Nan is a lawyer in the Beijing law firm, Hua Yi.

5. Zhang Qianfan is a professor at Peking University Law School.

6. Zhong Weijun attributes this concept to He Xuefeng and Liu Yue. See He Xuefeng and Liu Yue, "The 'zero-incident' logic in local management," Xueshu yanjiu - Academic research, no. 6, June 2010. 
lems. Zhong Weijun and Gao Jun say this logic forces the local authorities to deal with problems in a very superficial way. They spend more time trying to stop the authorities in charge of their evaluation from finding out about problems than they do on actually resolving them. The seriousness of a problem is judged only in terms of how higher authorities will perceive it. Zhong says this has contributed to a deterioration of relations between local authorities and citizens, as the relationship between the two has moved from one of service to one of "seizure" (juequ 箱取).

Under the system of letters and visits, local governments are supposed to contact and meet with petitioners (jiefang 接访). Xu Kai and Li Wei'ao show how, in practice, petitioners are obstructed (jiefang ) to keep local government evaluations artificially high. Local authorities use several different tactics to "buy peace" (huaqian mai ping'an 花钱买平安).

Petitioners' names are deleted from the official registers (xiaohao 销号). These lists of complainants are kept by the central government, and the evaluation of local authorities is partly based on them. Because of corruption and complicity between the local authorities and their direct superiors, the names of many petitioners are either not registered at all or are wiped off official registers in return for kickbacks. The Caijing journalists say that this turns the political problem of government evaluation into an economic cost.

Another option for local authorities is to arrest petitioners. This can be done locally through the "centres for maintaining stability" (weiwen ban 维稳办) at every administrative level. Local governments set up watch lists of likely nuisances, especially at times of important local festivals or around the annual plenary sessions of "the two assemblies" (the National People's Congress and the Chinese People's Political Consultative Conference) in Beijing. Gao Jun says that the political fallout from an incident on one of these occasions would be extremely serious. Xia Nan says local authorities have been known to issue fines or to illegally detain petitioners, sending them to work camps or psychiatric hospitals, in order to keep them from appealing to higher authorities. To encourage administrative staff to take action in this way, local governments have established a system of bonuses. Xu Kai and LiWei'ao say functionaries who resolved an "incident" at the village level earned bonuses of 50 or 100 yuan in 2011, and the reward is even greater for people further up the administrative ladder. Xu and Li say that the budget for "bonuses" in Guangdong's Yun'an District in 2010 was 20,000 yuan - extremely cost-effective compared with the potential political and economic cost of even one petitioner lodging a successful complaint in Beijing.

Local authorities can also carry out judgements on petitioners in Beijing through liaison offices (zhujing banshichu 驻京办事处). The president of a local court told the Caijing journalists that all young male judges are obliged to work in the Beijing liaison office of their locality, and that their main job is to be present at the High Court so as to keep petitioners from lodging complaints. Serious corruption is endemic in these liaison offices, since their main objective is to ingratiate themselves with the central authorities to win benefits for the locality they represent. Zhang Qianfan says that a corruption scandal in 2009 caused the central authorities to close many of these offices. Xu and Li say that in mid-2011, 625 liaison offices were closed, including 50 offices of provinces or special economic zones and 296 city offices.

But Beijing's decision to close the liaison offices only forced local governments to find another way to obstruct petitioners. Zhang says that even if the government shuts down one way of blocking petitioners, good evaluations for local authorities still depend on a lack of complaints reaching the central government. Local authorities therefore still need to find ways to prevent petitions from being lodged. One way to do this is to hire private companies to arrest the petitioners. As of mid-2011, the Beijing security company Anyuanding had signed contracts with 19 provinces to turn away, arrest, or detain petitioners in illegal detention centres, or black jails (hei jianyu 黑监狱). Zhang sees it as the height of cynicism that the effect of closing liaison offices was to enable these sordid enterprises to get rich.

Between wiping names from official registers, issuing bonuses to local staff for resolving "incidents," and hiring private enterprises to stop petitioners, a national market for stability maintenance is opening up. Zhang and the Caijing journalists see this market as the natural consequence of the current structure of stability maintenance and the method used to evaluate local governments. Zhang points out some positive developments, such as the closure of the liaison offices in Beijing and some innovations in the letters and visits system in Shenyang, Liaoning Province, where petitioners' cases are publicly heard in front of experts and deputies of the local People's Congress and Political Consultative Conference. But Zhang says that measures like the simple reform of the rules surrounding letters and visits cannot resolve these problems, which have their roots in the power relations of the petitioning system. As illustrated by the use of private enterprises to obstruct petitioners, local authorities can always just pay lip service to any new orders (yangfeng yinwei 阳奉阴违). Zhang criticises the letters and visits system as intrinsically unsuited to resolving local problems. He says that even if it were the concern of the central authorities to resolve local problems, they would need material and human resources that they simply do not have. As it stands, the system is structured so that citizens voice their problems and then go home - as if simply articulating them will somehow make them go away.

The system costs local governments a great deal in terms of both legitimacy and financial resources. Xia Nan says it is a vicious cycle that serves to reinforce the dual pressure on local governments from the people and from central authorities. The "mafiasation" (heisehua 黑色化) of the practices associated with maintaining social stability increases tensions between the government and the people, while the cost of these practices further financially weakens localities, and thus can affect local governments' evaluation by the central authorities. Xia says that in the long term, the most serious concern is the deterioration of the authorities' relations with the people, as well as relations among the people. He points to the toxic climate these methods create, giving the example of an old man denounced by the employees of a photocopy shop in Shanxi when they discovered he was preparing a petition file. After ten years, the current policy of maintaining stability has resulted in untenable fiscal practices and inconsistent results.

\section{Translated by Elizabeth Laederich.}

